\title{
The Exploration Classical Music Contribution to Improve Children's Memory Abilities
}

\author{
Zadrian Ardi1,* and Siti Azizi Fauziyyah ${ }^{2}$ \\ 1,2 Jurusan Bimbingan dan Konseling, Universitas Negeri Padang \\ *e-mail: zadrian@,fip.unp.ac.id
}

\begin{abstract}
Memory is a part of the brain that will be used until the old later. Today a great many children who have low memory. However, it is not a possibility many ways to develop your child's memory. Even the music was also influential in the power of memory. However, not all types of music can have a great impact against the child's memory. There are some kids who don't like the music even while being given or learn something. Therefore, this paper will discuss on the influence of music in improving memory or memory. Especially the kind of classical music. Some studies experts suggest that classical music is indeed influential in increasing memory. Because classical music has a quiet and relaxed tones that mostly used to study because it can lower the stress level when working as a matter of practice. In this case, the memory and the music are a collaboration that fit when working on the problem. Because it can improve memory and decrease stress.

Keywords: children's memory, classical music, classical music contribution.
\end{abstract}

\section{INTRODUCTION}

Human life will not be far away from the sound. Different types of voice has been widely studied by humans include a regular tone of voice with music. Based on language literature, music is sound composed and arranged in such a way so as to produce the song (Fujita, 2018), rhythm, and harmony is primarily from the sound generated from the tools that can generate rhythm (Buurman \& Jensen, 2018; Wai Chen, 2018). Everyone would want to be smart, genius, nimble, creative, talented and certainly successful. Although music is a kind of phenomenon of intuition, to create, refine and present it is an art form. A variety of types of music. Some of the wellknown pop, dangdut is the music, jazz and classical. The history of classical music is music that comes from the end of the 18th century the life composers Mozart and Hayden's later days known as the classic period due to the creation and presentation of classic wear musk properties (Rozin \& Rozin, 2018; Weber, 2017), form and style from the style of the past (Buurman \& Jensen, 2018; Fujita, 2018; Riley, 2017b).

Classical music itself is differentiated into non-Western music and popular music is due to the existence of differences in the connotations of her music. This can happen due to differences in the 16th century composers gives aintructions high to low tone that will be used to a bearer of music. Magic is the art of classical music because the music can affect people now listen to it (Borchardt \& Zoccola, 2018; Kellmann, Pelka, \& Beckmann, 2018). Some theories suggest that the information learned in a special mood and mood associated with the stimulus will be sorely needed in the learning environment to facilitate the process of recall (Chafin, Roy, Gerin, \& Christenfeld, 2004). Classical music has its own benefits compared to other types of music streams. 
More classical music has a greater benefit in lowering the level of stress and improve memory. A research on the selection of the type of music that is heard when working on a math problem, when someone listen this type of classical music's result proved more significant can lower stress and improve right on the type of memory other music (Chafin et al., 2004). Memory itself is the strength of the human spirit to receive, store and produce a return message and impression, understanding and intent or response as well as a disclaimer. our ability to learn very affected by memory. Without memory we will not be able to communicate with and without memory we cannot know ourselves or other people well (Dharmawan, 2016; Kurniawati \& Sipayung, 2015).

According to Siegel, classical music soothing alpha waves produce that can stimulate the limbic system of the brain neuron network (Susanti \& Rohmah, 2012). Classical music make the mind calm and always be able to continue to concentrate (Primadita, 2012), this could happen because classical music can balance the activity of the right and left cerebral hemispheres and also set the condition of brain waves to a beta or Alpha condition. Beta wave frequency alone is 12-25 $\mathrm{Hz}$, a frequency that is good to do activities that require high concentration. While alpha waves around 8-12 Hz is good to use for learning (Dalkner et al., 2017; Vossen, Gross, \& Thut, 2015).

Research conducted at Winona State University, the United States, said that a more classical music more influenced to improve memory in comparison to other types of music which was performed with the original version (Janus, Lee, Moreno, \& Bialystok, 2016; Nicolas, von Graevenitz, \& Fitch, 2018). Similar also with wants done on a bunch who listen to classical music is capable of remembering something versus who does not listen to music at all (Janus et al., 2016).

Facts about classical music is the reason researchers to conduct research. Because if linked back on benefits this classical music classical music can be used to improve memory in teenagers, then listen to this kind of music can be used as one of the methods that can be applied in the process of learning, so that easier in the given subject matter especially during exams or memorizing the material (Ardi, Ibrahim, \& Said, 2012; Ardi \& Yendi, 2013; Daharnis \& Ardi, 2016). Because according to Walberg and Green Berg social environment or atmosphere of the classroom is the determinant in the academic study of adolescent affected it (Ardi \& Erlamsyah, 2017; Ardi \& Maizura, 2018; Ardi \& Yendi, 2017).

\section{LITERATURE REVIEW}

\section{Memory}

A person's memory can be affected on the type of performance that require the ability, the experience that happened in the past can affect the thoughts or actions as for the foreseeable future (Aaboud et al., 2018; Abdillah, Anggarawati, \& Kananlua, 2013) and he explains there are 3 stages memory:

1. Encoding that information in memory,

2. Storage, which maintains the information in memory,

3. Memory retention, which took back the information from memory.

According to Atkinson, the three stages will not work the same way in all situations. Memory seems to be different according the situation requires that we save for a few seconds or until the year count (Endsley, 2017). This situation is called short term memory and long term. Short-term memory is a system that stores information is while being able to save the information to a limited extent. Short-term memory is a part that is usually information that is new (Hasson, Chen, \& Honey, 2015; Siemens, 2014; Zhang et al., 2016). Information coming into short term memory that stems from the sensory registers (central shelter sensory impressions) or long term 
memory system basis. Then Miller found that human short-term memory can only persist or save the information more or less 7 items, plus or minus.

\section{Classical Music}

Music is the language of conscience connected between comprehension and understanding between human beings in the corners of space and time (Riley, 2017a). "Without music, life would be an error" from this word can indicate how musical relationships with eratnya traits of humanity in the context of humanitarian entrants. Music is an integral part of human life, because the music is a vital aspect of a person's life which is also the basic ingredients of life that makes a person have a nature as human beings. In The New Encyclopedia Britanica music can be defined as the art of paying attention to the human voice or musical instrument in the form of sound (MacHenry \& Goetz, 1994). In music, a scientific dictionary is defined as a blend of sounds from a few tools or instruments are pitched on a regular basis and follow from.

The influence of music can improve academic ability because in addition can have a positive effect on life can also stimulate the academic success in a long period of time, because music can make someone easier in remembering (Ardoy et al., 2014). Campbell defines music as a universal language, contain elements that cross the boundaries of age, gender, race, religion, and nationality. Music can appear in all income levels, social class, and education (Carroll, 2018; Degé, Wehrum, Stark, \& Schwarzer, 2014; Hallam \& Council, 2015). Music speaks to everyone and to each species. Music is voices organized in time, art has a value and can be used as a tool to express ideas and emotions from the composer to the audience (Carroll, 2018).

For some people, the classic type of music might just music for musicians who are trained, singing by members of the choir or acoustic instruments that can be found in the Orchestra. But more than that classical music is also more difficult tounderstood because there is no definition of who can explain it clearly. Classical music is also not just music written later enjoyed but it has its own history and story than other types of music. According to Banoe (2003) classical music is a music of the past that always have discipline in its presentation; music is serious with the standard of classical works although created in the present (Gaspar et al., 2018; Wright, 2017). Classical music can be proven to give a meaningful influence on the person who hears it. In the study has also demonstrated to listen the classical music felt the calm and relaxed so that reduce feelings of worry. Meanwhile Lawrence he argues that classical music is also physiological condition influence because someone who listened to classical music will make your heart rate, blood pressure will drop and the muscles will be relaxed (Collingwood, 2016; de la Torre-Luque, Caparros-Gonzalez, Bastard, Vico, \& Buela-Casal, 2017; Neveux et al., 2016; Radstaak, Geurts, Brosschot, \& Kompier, 2014).

\section{METHODS}

This study uses a literature study approach by conducting in-depth analysis of various sources related to classical music's contribution to children's memory development. a review of the literature carried out takes sources and references from current research on the development of children's memory and its relation to classical music.

\section{RESULT AND DISCUSSION}

Study of two kinds of definition. The first is the process of acquiring knowledge. The second study is the ability to change the relactif lasting then react as hasi exercises have strengthened. Musical influences very strongly on the learning environment (Corrigall \& Schellenberg, 2015). Learning facilitated by the existence of the condition's relaxed and receptive because of the heartbeat someone under these circumstances range from 60 to 80 times per minute. If the human 
heart in the condition of learning will be more then or optimal due to incoming information will be easy to store the brain (Croom, 2015; Hodges \& Gruhn, 2018; Young \& Ilari, 2018).

When classical music was used for the background at the time studying, reading, or writing, will be a person focus and concentrate and also developed his thinking ability so that the new information sign in easier to remember. According to Gunawan (2007) there are 11 titles that played classical music which can be used could be learned, namely: Canon In D major works of Pachelbel, Fur Elise and adagio revision of 1. v. Beethoven, Water music by Handel, Frédéric Traumerei Scene from Robert Schumann, Nocturne In E A flat Major creation of Frederic Chopin, a String Quartet by f. j. Haydn, Andante Sonata In C the work of w. a. Mozart, Minuet of Luigi, THe Four Session Winter RV 267 revision of Antonio Vivaldi, and Minuet In G by j. s. Bach (Asmila, 2015; Hakimah \& Irianto, 2017; Muchtadi, Hartono, \& Oktaviana, 2017; Putri \& Khotimah, 2018). The 11th title this is used to increase the durability of the concentration. Deporter (2010) says the music tempo and pitch low intermediate between 70-80 bpm (bits per minute) will create the optimal learning conditions i.e. condition learned of the alert but still relaxed so that new information will be remembered more easily entry and will last long in the memory of someone.

The influence of the music of Mozart to concentrate on improving and changes in the activity of the neuro-physiological effect and will provide increased on subsequent perspective of spatial IQ test-space (Cabane, Hille, \& Lechner, 2015; Drăgulin \& $\square$ uteu, 2017). But the hormone thyroxine on high will cause individuals easily tired, and also anxious, grace period, and also hard to sleep. Therefore listen to music full of feeling peaceful and serene setting like classical music will also have an impact upon the psychic quieter and relaxes. By listening to music also affects the autonomic nervous menstimulus and (nerves nervous system) to be menstimulus other nervous so seserorang can feel at peace and quiet (relax) (Bernardi et al., 2017; Mukherjee, Palit, Banerjee, \& Bhattacharya, 2015; Ohira \& Marumo, 2017).

And on other discussion of classical music in the Baroque period resulted in heart rate and blood pressure speeds become more relaxed in accordance with the sound of beats in music, so that the body is relaxed and more alert and able to concentrate minds with easy. Later in Gunawan (2007) also expressed the human body has a long vibrating molecules level at a fixed and stable wave (Asmila, 2015; Hakimah \& Irianto, 2017). Music also has a vibration and frequency. When a person is listening music, then the frequencies of the music can be contradict or mingle with the frequency of the human body. If there is a commonality frequency, one will feel comfort and can implement witht thelearning process better, and can say someone is at a State of relaxed and alert (Bernardi et al., 2017; Drăgulin \& $\square$ uteu, 2017; Ohira \& Marumo, 2017).

Granting of classical music can increase the durability of the concentration in learning. The relationship between classical music giver with increased memory due to classical music can create an atmosphere that makes the physical condition of the soul and relax the conditions, with a high concentration of power that can easily understand the readings read and easy to remember. Classical music when used as background when studying, reading, or writing, can impact upon individuals, and create more focus and concentration because of this music can increase attention, memory and retention, and extend the time for focus on one thing at the same time develop the ability to think.

Now classical music used to test cognitive functions on various types of research. And summed up by Martin and Formanns that the music of Mozart can provide good effect in improving performance and spatial result even though someone's score was not significant. From the results of research that has been done can prove that classical music can be used as a way to improve memory especially short term memory in adolescents. Mozart's music can be influential in the development of improved study skills because the music Mozart was able to increase the passion of learning up to $36 \%$ compared to when it was learned not to listen to the music of 
Mozart (Cabane, Hille, \& Lechner, 2016; Ohira \& Marumo, 2017). This could happen because the music Mozart helps neurons-organizationneuoron existing on brain to strengthen the creative process of the brain associated with reasoning and the time that is the brain part right. So Mozart Music can smooth symmetric operations related to higher brain functions.

Mozart classical music also can give the effect of a decrease in a person's stress on simptom and can affect the body, mind, emotions resulting in calmness and peace so as to free his easier and more powerful memory because of these Circumstances can affect parts of the human brain that is connected to the hypothalamus. Proved by research conducted by Pratt, Abell and Skidmore (1995), he stated that classical music, especially classical music of Mozart, is known to improve the concentration of children so to remember the new information will be easier (Neveux et al., 2016; Radstaak et al., 2014).

When listening Mozart Music or music that can generally be used to evoke a feeling of relaxed because basically the music can indeed cause a relaxation to the audience so that the occurrence of the balance, the body's metabolism and hormonal. Mozart classical music can provide a positive influence for the audience (the subject of) the Mozart Music has functions and benefits on saturation (bunout) study, that of relaxation (peace of heart, give a sense of relaxed and comfortable), health (therapy reduces physical fatigue, heart rate), an increase in intelligence (cognitive affinity). and the expression and description of personality. Mozart's Music has a slow tempo as the Sonata for Two Pianos in D major is a masterpiece of Mozart that has slow intonation. The slow tempo of the music will provide a positive impact on someone and it will be easier to access and understanding of the mind due to the balanced condition in which all the functions of the physical person's slow and make body relax (Croom, 2015; Gaspar et al., 2018; Radstaak et al., 2014). So when new information comes in and will go on memory more durable due to optimal body condition to learn (vigilant but relaxed).

\section{CONCLUSION}

Classical music is indeed widely used to reduce tension and anxiety could be the learning process which will affect the strength of a person's memory. Classical music itself can be used as a companion to the media learned that creates the effect of a quiet and comfortable while learning. And also the music can indeed affect the brain and neuron-physiologic one's body in the process of study and can provide a positive learning outcomes. Is said to be positive because it gives positive results such as increasing concentration, improve memory to remember new information comes in, make the atmosphere relaxed and joyful learning. Of course if the learning atmosphere was like this and also high memory to learn then the result will be more satisfactory. It can be concluded also that Mozart owned classical music can indeed improve a person's memory because it can reduce the level of stress. And surely it would be more comfortable to execute someone in the learning process.

\section{REFERENCES}

Aaboud, M., Aad, G., Abbott, B., Abdallah, J., Abdinov, O., Abeloos, B., ... Abramowicz, H. (2018). Measurement of the W-boson mass in pp collisions at \&surd; $\$\{\$ s \$ \$=7 \mathrm{TeV}$ with the ATLAS detector. European Physical Journal C, 78.

Abdillah, W., Anggarawati, S., \& Kananlua, P. S. (2013). PENGUKURAN BATAS OPTIMAL KONSUMSI INTERNET SEHAT DAN PRODUKTIF DALAM MEDIA SOSLAL ONLINE. UNIVERSITAS BENGKULU.

Ardi, Z., \& Erlamsyah, E. (2017). Peningkatan Kualitas Penulisan Artikel Ilmiah bagi Kepala Sekolah. Jurnal Aplikasi IPTEK Indonesia, 1(1), 25-34. 
Ardi, Z., Ibrahim, Y., \& Said, A. (2012). Capaian Tugas Perkembangan Sosial Siswa dengan Kelompok Teman Sebaya dan Implikasinya terhadap Program Pelayanan Bimbingan dan Konseling. Konselor, 1(2).

Ardi, Z., \& Maizura, N. (2018). The Psychological Analysis of Divorce at Early Marriage. International Journal of Research in Counseling and Education, 1(3), 27-32. https://doi.org/10.24036/0026za0002

Ardi, Z., \& Yendi, F. M. (2013). Konseling Online: Sebuah Pendekatan Teknologi Dalam Pelayanan Konseling. Jurnal Konseling Dan Pendidikan, 1(1), 1-5.

Ardi, Z., \& Yendi, F. M. (2017). Students Attitude Towards LGBTQ; the Future Counselor Challenges. Jurnal Konseling Dan Pendidikan, 5(2), 74-79.

Ardoy, D. N., Fernández-Rodríguez, J. M., Jiménez-Pavón, D., Castillo, R., Ruiz, J. R., \& Ortega, F. B. (2014). A Physical Education trial improves adolescents' cognitive performance and academic achievement: the EDUFIT study. Scandinavian Journal of Medicine \& Science in Sports, 24(1), e52-e61.

Asmila, L. A. (2015). Pengaruh Strategi Genius Learning Berbasis Multiple Intelligences Terhadap Motivasi dan Hasil Belajar Siswa Kelas VIII SMP Negeri 2 Benjeng, Gresik pada Materi Getaran dan Gelombang. PENDIDIKAN SAINS, 3(02).

Bernardi, N. F., Codrons, E., Di Leo, R., Vandoni, M., Cavallaro, F., Vita, G., \& Bernardi, L. (2017). Increase in Synchronization of Autonomic Rhythms between Individuals When Listening to Music. Frontiers in Physiology, 8, 785.

Borchardt, A. R., \& Zoccola, P. M. (2018). Recovery from stress: an experimental examination of focused attention meditation in novices. Journal of Behavioral Medicine, 1-14.

Buurman, E., \& Jensen, O. C. (2018). Dancing the "Waterloo Waltz": Commemorations of the Hundred Days-Parallels in British Social Dance and Song. In Napoleon's Hundred Days and the Politics of Legitimacy (pp. 209-232). Springer.

Cabane, C., Hille, A., \& Lechner, M. (2015). Mozart or Pelé? The Effects of Teenagers Participation in Music and Sports.

Cabane, C., Hille, A., \& Lechner, M. (2016). Mozart or Pele? The effects of adolescents' participation in music and sports. Labour Economics, 41, 90-103.

Carroll, J. B. (2018). The model of school learning: Progress of an idea. In Time and School Learning (1984) (pp. 15-45). Routledge.

Chafin, S., Roy, M., Gerin, W., \& Christenfeld, N. (2004). Music can facilitate blood pressure recovery from stress. British Journal of Health Psychology, 9(3), 393-403.

Collingwood, J. (2016). The power of music to reduce stress. Psych Central, 17.

Corrigall, K. A., \& Schellenberg, E. G. (2015). Predicting who takes music lessons: Parent and child characteristics. Frontiers in Psychology, 6, 282.

Croom, A. M. (2015). Music practice and participation for psychological well-being: A review of how music influences positive emotion, engagement, relationships, meaning, and accomplishment. Musicae Scientiae, 19(1), 44-64. 
Daharnis, D., \& Ardi, Z. (2016). The Compatibility Student Choice of University Majoring; a Preliminary Studies. GUIDENA: Jurnal Ilmu Pendidikan, Psikologi, Bimbingan Dan Konseling, 6(1), 101-109.

Dalkner, N., Unterrainer, H. F., Wood, G., Skliris, D., Holasek, S. J., Gruzelier, J. H., \& Neuper, C. (2017). Short-term Beneficial Effects of 12 Sessions of Neurofeedback on Avoidant Personality Accentuation in the Treatment of Alcohol Use Disorder. Frontiers in Psychology, 8, 1688.

de la Torre-Luque, A., Caparros-Gonzalez, R. A., Bastard, T., Vico, F. J., \& Buela-Casal, G. (2017). Acute stress recovery through listening to Melomics relaxing music: a randomized controlled trial. Nordic Journal of Music Therapy, 26(2), 124-141.

Degé, F., Wehrum, S., Stark, R., \& Schwarzer, G. (2014). Music lessons and academic selfconcept in 12-to 14-year-old children. Musicae Scientiae, 18(2), 203-215.

Dharmawan, T. (2016). MUSIK KLASIK DAN DAYA INGAT JANGKA PENDEK PADA REMAJA. Jurnal Ilmiah Psikologi Terapan, 3(2), 370-382.

Drăgulin, S., \& Șuteu, C. L. (2017). Memory and learning: experiment on Sonata KV 331, in A Major by WA Mozart. Transilvania University of Brasov. Series VIII, Performing Arts, 10(1).

Endsley, M. R. (2017). Toward a theory of situation awareness in dynamic systems. In Situational Awareness (pp. 9-42). Routledge.

Fujita, R. (2018). Music education in modern Japanese society. In Studies on a Global History of Music (pp. 140-156). Routledge.

Gaspar, C. L. S., Danis, M. G. M., Dellosa, M. J. L., Leguin, B. L., Galdo, M. L. R., Macadangdang, L. J. B., \& Patindol, G. M. S. (2018). Classical Music: A Therapy for Reducing Stress during Latent Phase of Labor among Primigravida Women. Optima, 1.

Hakimah, I. N., \& Irianto, D. (2017). Pengaruh Metode Pembelajaran Genius Learning Terhadap Hasil Belajar Mata Pelajaran Identifikasi Ilmu bangunan Siswa Kelas X TGB SMK Negeri 3 Jombang. Jurnal Kajian Pendidikan Teknik. Bangunan, 1(1/JKPTB/17).

Hallam, S., \& Council, M. E. (2015). The power of music: A research synthesis of the impact of actively making music on the intellectual, social and personal development of children and young people. International Music Education Research Centre (iMerc).

Hasson, U., Chen, J., \& Honey, C. J. (2015). Hierarchical process memory: memory as an integral component of information processing. Trends in Cognitive Sciences, 19(6), 304-313.

Hodges, D. A., \& Gruhn, W. (2018). Implications of neurosciences and brain research for music teaching and learning. Music and Music Education in People's Lives: An Oxford Handbook of Music Education, 1, 206.

Janus, M., Lee, Y., Moreno, S., \& Bialystok, E. (2016). Effects of short-term music and secondlanguage training on executive control. Journal of Experimental Child Psychology, 144, 84-97.

Kellmann, M., Pelka, M., \& Beckmann, J. (2018). Psychological relaxation techniques to enhance recovery in sports. Sport, Recovery and Performance: Interdisciplinary Insights, 247-259.

Kurniawati, D., \& Sipayung, C. A. G. (2015). Iklan Manulife dan Brand Awareness (Studi Korelasional Analisis Iklan Manulife terhadap Brand Awareness Nasabah PT. Asuransi 
Jiwa Manulife Indonesia di Kota Medan). JURNAL SIMBOLIKA: Research and Learning in Communication Study, 1(1).

MacHenry, R., \& Goetz, P. W. (1994). The new encyclopaedia Britannica. Encyclopedia Britannica, Incorporated.

Muchtadi, M., Hartono, H., \& Oktaviana, D. (2017). Hubungan Aktivitas dan Respon terhadap Hasil Belajar Program Linier Setelah Diterapkan Pembelajaran Genius Learning pada Program Studi Pendidikan Matematika. Edu Sains: Jurnal Pendidikan Sains \& Matematika, $5(1), 45-55$.

Mukherjee, S., Palit, S. K., Banerjee, S., \& Bhattacharya, D. K. (2015). A comparative study on three different types of music based on same indian raga and their effects on human autonomic nervous systems. In Chaos, Complexity and Leadership 2013 (pp. 243-254). Springer.

Neveux, C., Ferard, M., Dickel, L., Bouet, V., Petit, O., \& Valenchon, M. (2016). Classical music reduces acute stress of domestic horses. Journal of Veterinary Behavior: Clinical Applications and Research, 15, 81.

Nicolas, E., von Graevenitz, A., \& Fitch, W. T. (2018). Bio-aesthetics and the aesthetic trajectory: A dynamic cognitive and cultural perspective. In Neuroaesthetics (pp. 59-101). Routledge.

Ohira, M., \& Marumo, A. (2017). Effects of listening to music prior to napping on endocrine and autonomic nervous system activity. Sleep Medicine, 40, e244-e245.

Primadita, A. (2012). Efektifitas Intervensi Terapi Musik Klasik Terbadap Stress Dalam Menyusun Skripsi Pada Mhasiswa PSIK Undip Semarang (PhD Thesis). Diponegoro University.

Putri, N. L., \& Khotimah, R. P. (2018). Penerapan Strategi Genius Learning Untuk Meningkatkan Kemampuan Pemahaman Konsep Dan Penalaran Siswa (PTK pada Siswa Kelas XI TKR 1 Semester Ganjil SMK Negeri 1 Blora Tabun 2017/2018) (PhD Thesis). Universitas Muhammadiyah Surakarta.

Radstaak, M., Geurts, S. A., Brosschot, J. F., \& Kompier, M. A. (2014). Music and psychophysiological recovery from stress. Psychosomatic Medicine, 76(7), 529-537.

Riley, M. (2017a). Liberal critics and Modern Music in the Post-Victorian age. In British Music and Modernism, 1895-1960 (pp. 29-46). Routledge.

Riley, M. (2017b). Musical listening in the German Enlightenment: attention, wonder and astonishment. Routledge.

Rozin, P., \& Rozin, A. (2018). Advancing Understanding of the Aesthetics of Temporal Sequences by Combining Some Principles and Practices in Music and Cuisine With Psychology. Perspectives on Psychological Science, 1745691618762339.

Siemens, G. (2014). Connectivism: A learning theory for the digital age.

Susanti, D. W., \& Rohmah, F. A. (2012). Efektivitas musik klasik dalam menurunkan kecemasan matematika (math anxiety) pada siswa kelas XI. HUMANITAS (Jurnal Psikologi Indonesia), 8(2), 129-142. 
Vossen, A., Gross, J., \& Thut, G. (2015). Alpha power increase after transcranial alternating current stimulation at alpha frequency ( $\alpha$-tACS) reflects plastic changes rather than entrainment. Brain Stimulation, 8(3), 499-508.

Wai Chen, J. C. (2018). Group creativity: mapping the creative process of a cappella choirs in Hong Kong and the United Kingdom using the musical creativities framework. Music Education Research, 20(1), 59-70.

Weber, W. (2017). Music and the middle class: the social structure of concert life in London, Paris and Vienna between 1830 and 1848. Routledge.

Wright, R. (2017). Sociology and music education. In Sociology and music education (pp. 23-42). Routledge.

Young, S., \& Ilari, B. (2018). Musical participation from birth to three: Toward a global perspective. Music Learning and Teaching in Infancy, Childhood, and Adolescence: An Oxford Handbook of Music Education, 2.

Zhang, Y., Chen, G., Yu, D., Yaco, K., Khudanpur, S., \& Glass, J. (2016). Highway long shortterm memory rnns for distant speech recognition. In Acoustics, Speech and Signal Processing (ICASSP), 2016 IEEE International Conference on (pp. 5755-5759). IEEE. 